\title{
Effectiveness of a comprehensive blood pressure control program in primary health care in Peru
}

\author{
Jong Koo Kim, ${ }^{1}$ Hye-yeon Jo, ${ }^{2}$ Miguel A. Malo, ${ }^{3}$ and Eun Woo Nam ${ }^{4}$
}

Suggested citation Kim JK, Jo H, Malo MA, Nam EW. Effectiveness of a comprehensive blood pressure control program in primary health care in Peru. Rev Panam Salud Publica. 2020;44:e18. https://doi.org/10.26633/RPSP.2020.18

ABSTRACT Objective. To assess the effectiveness of a comprehensive blood pressure (BP) control program on improving lifestyle indicators, BP levels, and laboratory examination results among people living in low-income urban areas of Peru.

Methods. A prospective before-and-after study design was applied to 1271 participants with hypertension or pre-hypertension. The intervention was implemented for 2 years, from May 2015 - April 2017, in three health centers in Lima ( 2 in Comas and 1 in Callao). The changes in participants over the study period were compared. All participants were provided with individualized consultations, group health education sessions, regular group meetings to improve self-management, and text messages providing health education. Paired t- and chi-square tests were used to determine the significance of the changes in indicators before and after the intervention.

Results. Lifestyle behaviors, such as weight and blood pressure monitoring, reduced salt consumption, increased fruit and vegetable consumption, and stress control improved during the intervention $(P<0.001)$. The EuroQol-Five Dimension Scale showed improvement $(P<0.001)$ and body mass index, waist circumference, and systolic and diastolic BPs of the participants significantly decreased $(P<0.001)$. Low-density lipoprotein cholesterol (LDL-C) and triglyceride decreased $(P<0.01)$ and high-density lipoprotein cholesterol (HDL-C) increased. The estimated glomerular filtration rate (eGFR) increased after the program $(P<0.001)$.

Conclusions. This comprehensive BP control program was effective in improving lifestyle indicators, BP levels, and laboratory results among people living in a low-income urban area of Peru. Increasing opportunities for BP measurement, systematic management of hypertensive patients, and community-based prevention and education programs are paramount to hypertension detection, prevention, and control.

Keywords Blood pressure; primary health care; healthy lifestyle; vulnerable populations; Peru.

Hypertension is one of the most critical worldwide public health issues because it promotes ischemic heart disease, cerebrovascular disease, and chronic kidney disease $(1,2)$. The 2015 Global Burden of Disease reported 79 risk factors associated with $41 \%$ of all disability-adjusted life years in 2015, among which high blood pressure (BP) was identified as the single most significant risk, even greater than smoking or obesity (3). An estimated 28 million people in low- and middle-income countries die annually from chronic, non-communicable disorders (NCDs; 4).

\footnotetext{
Department of Family Medicine, Wonju College of Medicine, Yonsei University, Wonju, Republic of Korea.

2 Yonsei Global Health Center, Yonsei University, Wonju, Republic of Korea.
}

Many studies have assessed the effectiveness of chronic disease management in primary care settings (5); for example, Pilleron and colleagues showed effective glycemic control and diabetes management in a primary health center under a chronic care model (6). Furthermore, several studies have reported the effectiveness of multi-component interventions, including the adoption of healthy lifestyles, to control $\operatorname{BP}(7,8)$.

In Peru, most deaths are caused by NCDs, among which cardiovascular disease accounts for a large proportion (9).

\footnotetext{
Pan American Health Organization/World Health Organization, Country Office, Lima, Peru.

4 Department of Health Administration, Yonsei University, Wonju, Republic of Korea. $₫$ Eun Woo Nam, ewnam@yonsei.ac.kr
} 
The prevalence of hypertension in Peru is approximately 20\%, which by international standards, is quite high; therefore, it is especially important to continuously manage hypertension through medication and effective lifestyle modifications (9). To accomplish this mission, management protocols that can productively utilize the capabilities available at the primary care level are crucial.

This study assessed the effectiveness of a comprehensive model for managing patients with high BP at the primary care level in low-income areas of Peru and verified the changes in lifestyle indicators, blood pressure profile, and laboratory examination results after participation in the intervention.

\section{MATERIALS AND METHODS}

\section{Study design}

A prospective before-and-after study design was applied to evaluate a comprehensive blood pressure control program (CBPCP). The project team conducted health screenings of the subjects before and after the intervention program, and analyzed changes over the study period. The study areas were Comas in northern Lima, and Callao, a seaside area on the western side of metropolitan Lima. The study was conducted in three health centers, two in Comas (Santa Luzmila and Laura Rodriguez) and one in Callao (Bellavista) over the 2-year period from May 2015 - April 2017. Comas and Callao were selected because this study aimed to evaluate the effectiveness of the CBPCP on vulnerable populations living in low-income areas of metropolitan Lima. Both study areas have comparably low socioeconomic status among districts in the Lima metropolitan area (10).

\section{Study sample}

The two criteria for study inclusion were age of 18 years or more and hypertensive or pre-hypertensive status. Individuals with $\mathrm{BP}$ in the hypertensive range $(\geq 140 / 90 \mathrm{mmHg})$ or with a current diagnosis of hypertension or who were taking $\mathrm{BP}$ medicine were categorized into the hypertension group. If the systolic BP was $\geq 120$ and $<140$ and the diastolic BP was $\geq 80$ and $<90$, the person was categorized in the pre-hypertension group.

A total of 1271 people were enrolled in the hypertension (1 071) and pre-hypertension (200) groups, 823 in Comas and 448 in Callao. The study participants were selected by measuring the $\mathrm{BP}$ of people visiting the health center or community events, using an automatic BP monitor (Omron ${ }^{\circledR}$ HEM-7113, Omron Healthcare Inc., Lake Forest, Illinois, United States of America). Individuals who met the criteria for hypertension or pre-hypertension received the intervention program.

We followed a four-step process to determine which individuals should be in each of the BP categories. First, the study participants were required to visit the program office in the health center at least 2 times in 1 week to have their BP measured by a health professional on the project team. If the participant was free of acute illness, the BP measurements were conducted twice on each arm in accordance with the standards set by the Seventh Report of the Joint National Committee on Prevention, Detection, Evaluation, and Treatment of High Blood Pressure (11). Second, if the average BP of the participant was in the higher range specified in our protocol, the candidate was referred to a medical doctor for a definitive diagnosis of pre-hypertension or hypertension. Third, the physician indicated the category in which the patient should be placed, as well as the appropriate management program, including medications, if any. At this point, an order was also created for clinical laboratory examinations. Fourth, after this exam, if appropriate, the doctor referred the participant to the office of the CBPCP for registration into the study and its interventional management program.

\section{Variables and measurements}

Data were obtained on the general characteristics of each subject, including sex, age, and visiting health center. Age was measured as a continuous variable, while the public health center visits were divided into three centers (Bellavista, Laura Rodriguez, and Santa Luzmila).

Knowledge variables related to hypertension were measured using a World Health Organization hypertension knowledge test containing nine questions, with a total score of $0-9$ points. Dietary knowledge variables were measured by responses to six questions on dietary habits. These questions were developed in consultation with Peruvian nutritionists in the program and in accordance with educational materials used in group health education sessions. Physical activity knowledge variables were measured by responses to six questions on physical activity. These questions were developed in consultation with the Peruvian nurses in the program and in accordance with the educational materials used in group health education sessions. Both dietary and physical activity knowledge were measured as continuous variables with values ranging from $0-6$ points.

Questions on lifestyle-related variables used a 4-point scale (not at all, sometimes, frequently, always) to ask about weight and diet control activities, fruit and vegetable intake, fried food intake, blood pressure measurement, and stress reduction in the previous 30 days.

Moderate physical activity was defined as intense physical activity $\geq 20$ minutes a day on $\geq 3$ days during the past week ( 7 days); or moderate physical activity for $\geq 30$ minutes a day on $\geq 5$ days during the past week. The definition of walking was walking for $\geq 10$ minutes on $\geq 3$ days during the past week. Variables related to moderate physical activity and walking were measured using the International Physical Activity Questionnaire (IPAQ; 12).

Current smoking was defined as having smoked $\geq 100$ cigarettes during the lifetime and smoking $\geq 1$ cigarette every day or sometimes. For participants who reported consuming alcohol in the past year (365 days), high-risk drinking was defined as the consumption of $\geq 7$ glasses at one time and more than twice a week for men, and $\geq 5$ glasses at one time and more than twice a week for women.

Changes in health status were used as variables for physiological indicators. BP, body mass index (BMI), waist circumference, and blood and urine indices were measured as physiological indicators. BP was measured using an automatic BP monitor after the subjects had rested for 5 minutes. The subjects' upper arms were measured twice at heart height and the values were averaged. Both systolic and diastolic BP were measured.

Height was measured using an extensometer. Weight was measured with a scale. BMI was calculated using the individual's height and weight $\left(\mathrm{kg} / \mathrm{m}^{2}\right)$. Waist circumference was 
measured using a tape measure placed horizontally above both pelvic bones and across the navel. Blood and urine indices were measured in each subject using clinical tests performed at the clinical laboratories in the public health center, before and after the intervention program. Measurements included total cholesterol, high-density lipoprotein cholesterol (HDL), low-density lipoprotein cholesterol (LDL), triglyceride, fasting blood glucose, and creatinine levels, as well as hemoglobin, hematocrit, and estimated glomerular filtration rate (eGFR).

Assessment of the subjects' quality of life was measured using the EuroQol Five Dimension Scale (EQ-5D) tool developed by EuroQol (13). It uses a 3-point scale (not/somewhat/ very) in response to five questions: ability to exercise, self-care, daily activities, pain/discomfort, and anxiety/depression.

When a comparison of before and after was not possible due to missing data in any variable, the participant was excluded from the analysis of that specific variable.

\section{Data collection and statistical analysis}

The study data were the records of the participants' health screening results, before and after the CBPCP. The data were recorded by nurses and nutritionists in the three public health centers selected for the study. The results of the tests conducted by the clinical laboratory were also collected by program health personnel.

Data were collected through an Internet-based system used by the project team members in each health center to populate a database. All analyses were performed using IBM SPSS ${ }^{\circledR}$ Statistics, version 21 (IBM Corp., Armonk, New York, United States). Paired T-tests were used to compare quantitative indicators, such as anthropometric values, the clinical laboratory results, and quality of life, before and after the intervention. The level of significance was set at $5 \%$ for all analyses. Chi-square tests were used to determine the significance of changes in lifestyle.

\section{Description of program interventions}

All participants were provided specific services; namely, individualized consultations, group health education sessions, regular group meetings to improve self-management, and mobile and interactive health interventions in the form of text messages. These interventions are described in Table 1.

Individual consultations. Over 12 weeks, each of the participants received 8 personal consultations.

During the 1st and 8th consultations, the health status of each participant was reviewed in detail by a nurse, nutritionist, laboratory technologist, and a medical doctor. One component of this screening was a needs-analysis table populated with health information for each subject, including anthropometric measures, family history of chronic diseases, extent of healthy living knowledge, daily habits, and quality of life as measured by the EQ-5D. The second component of these consultations was a clinical laboratory examination that included a lipid profile (triglyceride, LDL, HDL, total cholesterol) and metrics regarding fasting glucose, hemoglobin, hematocrit, and creatinine levels, as well as eGFR.

The 8 consultations were made up of 4 visits at the health center, 2 home visits, and 2 discussions by mobile phone. All were conducted by a nurse practitioner, nutritionist, social worker, or psychologist. During these consultations, each subject was provided a variety of materials for self-management of their BP and lifestyle. In the first session, three types of diaries were provided to each subject: one for BP readings, one for daily food consumption, and a third for physical activity. The health practitioner explained the use of these diaries. The participants were required to bring the diaries to each consultation because counseling was based on the diary records. At each of these counseling sessions, BP, weight, and waist circumference were measured.

TABLE 1. Description of the Comprehensive Blood Pressure (BP) Control Program intervention conducted eight times for 12 weeks in May 2015 - April 2017 in three health centers in Lima and Callao, Peru

\begin{tabular}{|c|c|c|}
\hline Week & Activities & Place / Form \\
\hline 1 & $\begin{array}{l}\text { - Health screening: need analysis, clinical laboratory exam } \\
\text { - Provision of diaries for self-recording }\end{array}$ & Health center \\
\hline 2 & $\begin{array}{l}\text { - Measurement of BP, weight, and waist circumference } \\
\text { - Individual counseling: healthy lifestyle behaviors (review diary records of each participant) }\end{array}$ & Health center \\
\hline 4 & $\begin{array}{l}\text { - Measurement of BP, weight, and waist circumference } \\
\text { - Individual counseling: healthy lifestyle behaviors } \\
\text { - Group health education session (1st) }\end{array}$ & Home visit \\
\hline 6 & $\begin{array}{l}\text { - Measurement of BP, weight and waist circumference } \\
\text { - Individual counseling: healthy lifestyle behaviors education } \\
\text { - Group health education session (2nd) }\end{array}$ & Phone call \\
\hline 8 & $\begin{array}{l}\text { - Measurement of BP, weight, and waist circumference } \\
\text { - Individual counseling: healthy lifestyle behaviors } \\
\text { - Group health education session (3rd) }\end{array}$ & Home visit \\
\hline 10 & $\begin{array}{l}\text { - Measurement of BP, weight, and waist circumference } \\
\text { - Individual counseling: healthy lifestyle behaviors } \\
\text { - Group health education session (4th) }\end{array}$ & Phone call \\
\hline 12 & $\begin{array}{l}\text { - Measurement of BP, weight, and waist circumference } \\
\text { - Individual counseling: healthy lifestyle behaviors } \\
\text { - Group health education session (5th) } \\
\text { - Health screening: need analysis, clinical laboratory exam }\end{array}$ & Health center \\
\hline
\end{tabular}


Group health education sessions. In addition to the individual counseling sessions, there were group meetings led by a health professional. The original versions of the educational materials were developed by the Korean Centers for Disease Control and Prevention in 2015 (14) and translated into Spanish. In consultation with national health experts, including the chief of the Division of Health Promotion at the Ministry of Health of Peru, certain modifications were made to nutritionrelated information, such as the standard for salt intake. Group meetings addressed five themes: hypertension risk factors and complications; healthy diet for blood pressure control; theory behind using physical activity for BP control; practical use of physical activity for BP control; and mental health techniques for controlling BP.

Regular group meetings to improve self-management. These sessions provided informational and emotional support by giving participants a place to share personal challenges encountered during the study period, as well as positive experiences resulting from behavior changes. The group meetings were held once weekly, for a total of 8 meetings per person. They included training on how to prepare healthy foods, methods for managing mental health issues, and even recreational activities such as dancing and group games.

Mobile health intervention through text messages. The project team sent messages promoting a healthy lifestyle twice weekly to all participants. These communications addressed five specific subjects: salt and sodium consumption, e.g., "Si quitas el salero de la mesa, ayudarás a tu familia a comer con menos sal"; fruit and vegetable consumption, e.g., "¿Ya comiste alguna fruta o verdura hoy? Trata de comer al menos una en cada comida"; consumption of foods containing high cholesterol and sugar levels, e.g., "Que bueno que comes menos dulces y bebidas con azúcar. Así cuidas tu corazón"; physical activity, e.g.,
"Hacer actividad física ha sido una excelente decisión. ¡Sigue adelante!"; and medication adherence, e.g., "Sr./Sra. toma tu medicación para la hipertensión hoy."

\section{Ethics}

Ethical approval for the study was obtained from the Institutional Review Board of the Wonju Campus of Yonsei University, Wonju, Republic of Korea (IRB Number: 1041849-201410-BM048-02). Informed consent was provided by each individual before completing the questionnaire or the clinical laboratory examination. The survey data were confidential and were provided only to the participant and health professionals for case management and to the researchers for study.

\section{RESULTS}

A total of 1271 participants with high blood pressure were enrolled in the CBPCP. The mean age (SD) was 62.2 years $( \pm 10.86) ; 27.8 \%$ of participants were 70 years of age or more; and $64.0 \%$ were women (Table 2). The ratios of pre-hypertension to hypertension in Bellavista, Laura Rodriguez, and Santa Luzmila were 0.13 (53/395), 0.23 (79/342), and 0.20 (68/334), respectively (Table 2). Only $5.7 \%$ of participants were smokers; $9.1 \%$ had moderate physical activity; and $12.0 \%$ were categorized as drinkers; more specifically, $0.3 \%$ were in the high-risk drinking group (Table 2). The ratio of patients using antihypertensive medication in the hypertension group was 0.87 (929/1 071).

\section{Comparisons of lifestyle indicators before and after intervention}

Table 3 shows the results of lifestyle indicators. There was generally good participant compliance. In particular, 1203

TABLE 2. General characteristics of the subjects of Comprehensive Blood Pressure Control Program (СВPCP) implemented in three health centers in Lima and Callao in Peru from May 2015 to April 2017: Comparisons according to blood pressure group based on pre-hypertension and hypertension status

\begin{tabular}{|c|c|c|c|}
\hline & Pre-hypertension $(n=200)$ & Hypertension ( $n=1071$ ) & Total $(N=1271)$ \\
\hline Age, years & $58.30 \pm 11.43$ & $62.95 \pm 10.61$ & $62.21 \pm 10.86$ \\
\hline \multicolumn{4}{|l|}{ Age group, years } \\
\hline $20-49$ & $46(23.0)$ & $117(10.9)$ & $163(12.8)$ \\
\hline $50-59$ & $61(30.5)$ & $258(24.1)$ & $319(25.1)$ \\
\hline $60-69$ & $58(29.0)$ & $377(35.2)$ & $435(34.2)$ \\
\hline$\geq 70$ & $35(17.5)$ & $319(29.8)$ & $354(27.8)$ \\
\hline Women & $124(62.0)$ & $689(64.3)$ & $813(64.0)$ \\
\hline \multicolumn{4}{|l|}{ Health center, district } \\
\hline Bellavista, Callao & $53(26.5)$ & 395 (36.9) & $448(35.2)$ \\
\hline Laura Rodriguez, Comas & $79(39.5)$ & $342(31.9)$ & $421(33.1)$ \\
\hline Santa Luzmila, Comas & $68(34.0)$ & $334(31.2)$ & $402(31.6)$ \\
\hline Non-smoker & $185(92.5)$ & $1014(94.7)$ & $1199(94.3)$ \\
\hline Moderate physical activity & $25(12.5)$ & $91(8.5)$ & $116(9.1)$ \\
\hline Walking & $58(29.0)$ & $374(34.9)$ & $433(34.1)$ \\
\hline Drinking & $31(15.5)$ & $121(11.3)$ & $152(12.0)$ \\
\hline High-risk drinking status & $1(0.5)$ & $3(0.3)$ & $4(0.3)$ \\
\hline Antihypertension medication & $0(0.0)$ & $929(86.7)$ & $929(73.1)$ \\
\hline
\end{tabular}

Nource: Continuous variables are represented as means \pm standard deviations and categorical variables as numbers and ratios.
Notion 
TABLE 3. Comparison of lifestyle indicators of the subjects before and after participation in the Comprehensive Blood Pressure Control Program (CBPCP) implemented in three health centers in Lima and Callao in Peru from May 2015 to April 2017

\begin{tabular}{|c|c|c|c|c|}
\hline & Total number & Before & After & P-value ${ }^{a}$ \\
\hline Weight monitoring, $(n, \%)$ & 1203 & $230(19.1)$ & $663(55.1)$ & $<0.001$ \\
\hline Reduction of salt consumption $(n, \%)$ & 1204 & $570(47.4)$ & $924(76.7)$ & $<0.001$ \\
\hline Consumption of fruits or vegetables $(n, \%)$ & 1191 & $583(49.0)$ & $880(73.9)$ & $<0.001$ \\
\hline Blood pressure monitoring $(n, \%)$ & 1185 & $348(29.4)$ & $804(67.8)$ & $<0.001$ \\
\hline Practice of stress control $(n, \%)$ & 1182 & $234(19.8)$ & $504(42.6)$ & $<0.001$ \\
\hline Drinking $(n, \%)$ & 1271 & $152(12.0)$ & $87(6.8)$ & $<0.001$ \\
\hline Present high-risk drinking $(n, \%)$ & 1271 & $4(0.3)$ & $3(0.2)$ & $<0.001$ \\
\hline Body mass index & 1248 & $29.51 \pm 5.05$ & $28.94 \pm 4.93$ & $<0.001$ \\
\hline Waist circumference & 1243 & $96.77 \pm 10.84$ & $95.67 \pm 10.53$ & $<0.001$ \\
\hline$E Q-5 D$ & 1271 & $0.85 \pm 0.12$ & $0.87 \pm 0.11$ & $<0.001$ \\
\hline
\end{tabular}

Source: Prepared by the authors based on the study results.

Note: Weight monitoring, reduced salt consumption, fruit or vegetable consumption, avoidance of fried or junk foods, blood pressure monitoring, and stress control were considered to be present when subjects answered "frequently" or "always" and absent for "never" or "sometimes".

EQ-5D: EuroQol Five Dimension Scale

${ }^{a} \mathrm{p}$-values were calculated using paired $\mathrm{t}$-tests for body mass index (BMI), waist circumference, and EQ-5D and chi-square tests for the other variables.

TABLE 4. Comparison of blood pressure profile of the subjects before and after participation in the Comprehensive Blood Pressure Control Program (CBPCP) implemented in three health centers in Lima and Callao in Peru from May 2015 to April 2017

\begin{tabular}{lcccc} 
& Total number & Before & After & P-value \\
$\begin{array}{lcccc}\text { Antihypertension } \\
\text { medication }\end{array}$ & 1071 & $929(86.7)$ & $1043(97.4)$ & $<0.001$ \\
Systolic BP & 1271 & $135.85 \pm 20.29$ & $125.05 \pm 17.64$ & $<0.001$ \\
Diastolic BP & 1271 & $74.87 \pm 18.08$ & $71.29 \pm 11.04$ & $<0.001$ \\
\hline
\end{tabular}

Source: Prepared by the authors based on the study results.

ap-values were calculated using chi-squared tests for antihypertension medication and paired t-tests for systolic and diastolic BP.

participants thoroughly answered the questions on weight monitoring, both before and after the intervention program; 1204 regarding salt consumption; and 1191 regarding fruits and vegetables. Physical activity levels did not change with the intervention program; however, all other lifestyle indicators improved: increased monitoring of weight and BP, decreased salt and junk food consumption, increased fruit and vegetable consumption, and stress control improved. Furthermore, both drinking alcohol and smoking significantly decreased after the intervention program. Also, the EQ-5D, a metric to assess the quality of life, showed improvement $(0.85-0.87)$, while average BMI $\left(29.5-28.9 \mathrm{~kg} / \mathrm{m}^{2}\right)$ and average waist circumference $(96.8-95.7 \mathrm{~cm})$ decreased significantly throughout the program.

\section{Comparison of blood pressure before and after intervention}

The ratio of anti-hypertension medication use increased from $73.1 \%$ to $82.1 \%$, and both systolic and diastolic BP decreased (Table 4). As a result of the intervention program, 114 participants with hypertension received new prescriptions for
TABLE 5. Comparison of laboratory examination results of the subjects before and after participation in the Comprehensive Blood Pressure Control Program (CBPCP) implemented in three health centers in Lima and Callao in Peru from May 2015 to April 2017

\begin{tabular}{|c|c|c|c|c|}
\hline & Total number & Before & After & P-value ${ }^{a}$ \\
\hline Total cholesterol & 609 & $207.16 \pm 47.48$ & $202.27 \pm 49.02$ & 0.012 \\
\hline $\begin{array}{l}\text { Low-density lipoprotein } \\
\text { cholesterol }\end{array}$ & 501 & $132.12 \pm 41.42$ & $126.53 \pm 42.16$ & 0.007 \\
\hline $\begin{array}{l}\text { High-density lipoprotein } \\
\text { cholesterol }\end{array}$ & 24 & 57 & 92 & 0.018 \\
\hline Triglyceride & 606 & $165.85 \pm 92.11$ & $156.83 \pm 89.34$ & 0.007 \\
\hline Glucose & 606 & $102.68 \pm 36.42$ & $100.51 \pm 34.32$ & 0.122 \\
\hline Creatinine & 265 & $1.03 \pm 0.84$ & $0.94 \pm 0.65$ & 0.073 \\
\hline Hemoglobin & 539 & $13.66 \pm 1.36$ & $13.58 \pm 1.36$ & 0.154 \\
\hline Hematocrit & 446 & $41.16 \pm 4.05$ & $40.54 \pm 4.28$ & 0.001 \\
\hline Estimated glomerular & 269 & $78.66 \pm 42.68$ & $85.47 \pm 47.37$ & $<0.001$ \\
\hline
\end{tabular}

filtration rate

Source: Prepared by the authors based on the study results.

ap-values were calculated using paired t-tests.

antihypertensive medication from qualified medical doctors at the study's health centers. The antihypertensive medications included captopril, enalapril, and losartan (Farmindustria, Lima, Peru).

\section{Comparison of laboratory examination results before and after intervention}

The laboratory examination results showed that lipid profiles-known risk factors for cardiovascular diseasedecreased for LDL-C and triglycerides and increased for HDL-C (Table 5). Likewise, fasting glucose, as well as eGFR and creatinine (kidney status) were lower after the program. 


\section{DISCUSSION}

The results of this study showed that a CBPCP effectively reduced the mean systolic $\mathrm{BP}$ and generated other beneficial results in a low-income urban area of Peru. While numerous community-based interventions have been assessed for the prevention of cardiovascular diseases in low- and middleincome countries (15), this intervention program simultaneously accomplished many of the goals attempted by various and more narrowly-aimed efforts.

Previous interventions have employed different study designs, including randomized controlled trials (16), cluster controlled trials $(17,18)$, interventional trials $(19)$, and non-controlled experiments (20). Furthermore, the various interventions have included health education (21) and nutrition training (22) of both individuals and groups, and specially developed clinics (23). However, the present study used an intervention trial and simultaneously employed numerous validated interventions, including medical treatment, health education, exercise training, salt reduction, and nutrition training. Previous interventional studies aimed at achieving BP control at the community level; for example, the Hypertension Control Program in Argentina (HCPIA) trials were a cluster of randomized efforts that deployed a community health worker-led multi-component intervention over 18 months to lower systolic and diastolic BP. HCPIA included health coaching, home BP monitoring, physician education, BP feedback, and weekly text messaging, and yielded systolic and diastolic $\mathrm{BP}$ reductions of 19.3 and $12.7 \mathrm{mmHg}$, respectively (24). Mills and colleagues assessed the comparative effectiveness of eight implementation strategies for BP control in adults with hypertension, reporting that team-based care with medication titration by a non-physician was the most effective alternative and produced a systolic BP reduction of $7.1 \mathrm{mmHg}$ (17). Comparably, ours employed team-based care by non-physicians and conducted medication titration, with a systolic BP reduction of $10.80 \mathrm{mmHg}$.

After our intervention, the habit of BP monitoring increased from $29.4 \%$ to $57.8 \%$. A 2010 study also demonstrated the effectiveness of education on BP self-monitoring in patients with hypertension based on the Beliefs, Attitudes, Subjective Norms, and Enabling Factors model (25).

Through a multi-approach intervention that included educational materials and individualized consultations, the present study showed changes in major lifestyle metrics. Many studies have assessed the association between such lifestyle elements and the risk of hypertension. Reports in the United States estimated that alcohol might account for close to $10 \%$ of the population's burden of hypertension (23). Moreover, both smoking and hypertension are synergistic risk factors for cardiovascular diseases, including myocardial infarction and stroke (26).

\section{Limitations}

This study has several limitations. The participant selection process and relatively high attendance rates might have led to sample selection bias. Most of the subjects were patients or their family members who visited the health centers where this project was based, as well as non-related individuals who regularly visited other health centers. Therefore, our sample may have included people with an above-average level of interest in their health. Concerning the data collection, there is the potential for misclassification because data were self-reported. Also, as this study was not a randomized controlled trial, it is limited in determining the independent effects of the intervention. To overcome this limitation, future work should select a control group in the same community as the health center and similar to the area in which the intervention is conducted. Finally, since this study was undertaken in low- and middle-income urban communities in Peru, our results are not generalizable to the entire Peruvian population.

The strengths of this study are the assessment of the effects on BP control and cardiometabolic outcomes in the context of a comprehensive intervention in a limited-resource setting.

\section{Conclusions}

The study findings showed the effectiveness of a comprehensive $\mathrm{BP}$ control program to improve lifestyle indicators, BP levels, and laboratory examination results among people who live in a low-income urban area of Peru and participated in the CBPCP intervention. Increased awareness is needed of the importance of measuring blood pressure and of providing blood pressure monitors in public places so that community members can regularly check their BP. There is also a need for systematic management of patients diagnosed with hypertension.

Increasing opportunities for BP measurement, systematic management of hypertensive patients, and community-based prevention and education programs are paramount to concurrently improving hypertension detection, prevention, and control. This program model could be expanded to other areas of Peru and could inform relevant models in other Latin American countries.

Author contributions. EWN conceived the original idea. JKK planned the experiments. HJ collected and analyzed the data. MAM supported the experiment and provided the WHO guideline. All authors participated in writing the paper. All authors reviewed and approved the final version.

Acknowledgements. The authors thank the study participants, the health professionals who worked for the intervention program, and all other partners in Peru who made the research available.

\section{Conflicts of interest. None declared.}

Funding. This work was supported by the Korea International Cooperation Agency under the title of 'Health Promotion Program in Lima North and Callao, 2014 - 2017' (P201300151-1). The funders had no role in the study design, data collection or analysis, decision to publish, or preparation of the manuscript.

Disclaimer. Authors hold sole responsibility for the views expressed in the manuscript, which may not necessarily reflect the opinion or policy of the RPSP/PAJPH and/or PAHO. 


\section{REFERENCES}

1. World Health Organization. Global Action Plan for the Prevention and Control of Noncommunicable Diseases 2013-2020. Geneva: WHO; 2013. Available from: https://www.who.int/nmh/events/ ncd_action_plan/en Accessed 10 August 2019.

2. Vinay K, Abul KA, Jon CA. Robbins and Cotran Pathologic Basis of Disease, $9^{\text {th }}$ ed. London: Elsevier; 2014. Pp. 533-4.

3. Forouzanfar MH, Alexander L, Anderson HR, Bachman VF, Biryukov S, Brauer M, et al. Global, regional, and national comparative risk assessment of 79 behavioural, environmental and occupational, and metabolic risks or clusters of risks in 188 countries, 1990-2013: a systematic analysis for the Global Burden of Disease Study 2013. Lancet. 2015;386(10010):2287-323.

4. Beaglehole R, Epping-Jordan J, Patel V, Chopra M, Ebrahim S, Kidd $\mathrm{M}$, Haines A. Improving the prevention and management of chronic disease in low-income and middle-income countries: a priority for primary health care. Lancet. 2008;372(9642):940-9.

5. Dennis SM, Zwar N, Griffiths R, Roland M, Hasan I, Powell Davies $\mathrm{G}$, et al. Chronic disease management in primary care: from evidence to policy. Med J Aust. 2008;188:S53-6.

6. Pilleron S, Pasquier E, Boyoze-Nolasco I, Villafuerte JJ, Olchini D, Fontbonne A. Participative decentralization of diabetes care in Davao City (Philippines) according to the Chronic Care Model: A program evaluation. Diabetes Res Clin Pract. 2014;104(1):189-95.

7. Jiang H, Vilma I, Katherine TM, Rosana P, Andrea B, Jacquelyn D, et al. Effect of a community health worker-led multicomponent intervention on blood pressure control in low-income patients in Argentina. JAMA. 2017;318(11):1016-25.

8. Balcázar H, Fernández-Gaxiola AC,Pérez-Lizaur AB, Peyron RA, Ayala C. Improving heart healthy lifestyles among participants in a Salud para su Corazón promotores model: the Mexican pilot study, 2009-2012. Prev Chronic Dis. 2015;12:E34.140292.

9. Ministry of Health of Peru. Carga de enfermedad en el Peru: estimacion de los años de vida saludable perdidos 2012. Lima: MOH; 2014.

10. Instituto Nacional de Estadística e Informática. Una mirada a Lima metropolitana. Lima: INEI; 2014.

11. Chobanian AV, Bakris GL, Black HR, Cushman WC, Green LA, Izzo Jr JL, et al. Seventh report of the Joint National Committee on Prevention, Detection, Evaluation, and Treatment of High Blood Pressure. Hypertension. 2003;42(6):1206-52.

12. The International Physical Activity Questionnaire Group. International Physical Activity Questionnaire. 2010. IPAQ_Spanish (Argentina) short last 7 days self-administered format; 2011. Available from: www.ipaq.ki.se Accessed 11 November 2019.

13. EuroQol Research Foundation. EQ-5D. Rotterdam: EuroQol Research Foundation; 1990. Available from: https://euroqol.org/ eq-5d-instruments/eq-5d-3l-about/ Accessed 11 November 2019.

14. Korea Center for Disease Control and Prevention. Standard Educational Materials of Hypertension. Osong, Republic of Korea: KCDC; 2012. Available from: http:/ / www.cdc.go.kr/board.es?mid=a20503 $050000 \&$ bid $=0021 \&$ act $=$ view\&list_no $=127690$ Accessed 11 November 2019.

15. van de Vijver S, Oti S, Addo J, de Graft-Aikins A, Agyemang C. Review of community-based interventions for the prevention of cardiovascular diseases in low-and-middle-income countries. Ethn Health. 2012;17(6):651-76.

16. Jafar TH, Islam M, Hatcher J, Hashmi S, Bux R, Khan A, et al. Community based lifestyle intervention for blood pressure reduction in children and young adults in developing country: cluster randomised controlled trial. BMJ. 2010;340:c2641.

17. Mills KT, Obst KM, Shen W, Molina S, Zhang $\mathrm{H}$, He $\mathrm{H}$, et al. Comparative effectiveness of implementation strategies for blood pressure control in hypertensive patients. Ann Intern Med. 2018; 168(2):110-20.

18. Neupane D, McLachlan CS, Mishra SR, Olsen MH, Perry HB, Karki A, et al. Effectiveness of a lifestyle intervention led by female community health volunteers versus usual care in blood pressure reduction (COBIN): an open-label, cluster-randomised trial. Lancet Glob Health. 2018;6(1):e66-73.

19. Huang S, Hu X, Chen H, Xie D, Gan X, Wu Y, et al. The positive effect of an intervention program on the hypertension knowledge and lifestyles of rural residents over the age of 35 years in an area of China. Hypertens Res. 2011;34(4):503-8.

20. Almeida-Pittito Bd, Hirai AT, Sartorelli DS, Gimeno SGA, Ferreira SRG. Impact of a 2-year intervention program on cardiometabolic profile according to the number of goals achieved. Braz J Med Biol Res. 2010;43(11):1088-94.

21. Calano BJD, Cacal MJB, Cal CB, Calletor KP, Guce FICC, Bongar MVV, Macindo JRB. Effectiveness of a community-based health programme on the blood pressure control, adherence and knowledge of adults with hypertension: A PRECEDE-PROCEED model approach. J Clin Nurs. 2019;28(9-10);1879-88.

22. Damião R, Sartorelli DS, Hirai A, Massimino F, Poletto J, Bevilacqua $M R$, et al. Nutritional intervention programme among a Japanese-Brazilian community: procedures and results according to gender. Public Health Nutr. 2010;13(9):1453-61.

23. Krishnan A, Ekowati R, Baridalyne N, Kusumawardani N, Suhardi, Kapoor SK, et al. Evaluation of community-based interventions for non-communicable diseases: experiences from India and Indonesia. Health Promot Int. 2011;26(3):276-89.

24. He J, Irazola V, Mills KT, Poggio R, Beratarrechea A, Dolan J, et al. Effect of a community health worker-led multicomponent intervention on blood pressure control in low-income patients in Argentina: a randomized clinical trial. JAMA. 2017;318:1016-25.

25. Baghianimoghadam MH, Rahaee Z, Morowatisharifabad MA, Sharifirad G, Andishmand A, Azadbakht L. Effects of education on self-monitoring of blood pressure based on BASNEF model in hypertensive patients. J Res Med Sci Off J Isfahan Univ Med Sci. 2010;15:70.

26. Whelton PK, Carey RM, Aronow WS, Casey DE Jr, Collins KJ, Dennison HC, et al. 2017 ACC/AHA/AAPA/ABC/ACPM/AGS/ APhA/ASH/ASPC/NMA/PCNA Guidelines for the Prevention, Detection, Evaluation, and Management of High Blood Pressure in Adults: A Report of the American College of Cardiology/American Heart Association Task Force on Clinical Practice Guidelines. J Am Coll Cardiol. 2018;71(19):2275-9.

Manuscript received on 19 August 2019. Revised version accepted for publication on 20 November 2019. 


\section{Efectividad de un programa de control integral de la presión arterial en la atención primaria de salud en Perú}

RESUMEN Objetivo. Evaluar la efectividad de un programa de control integral de la presión arterial (PA) para mejorar los indicadores relativos al modo de vida, los niveles de PA y los resultados de laboratorio en personas que viven en zonas urbanas de ingresos bajos en Perú.

Métodos. Mediante un estudio prospectivo se analizó la situación antes y después de 1.271 personas que presentaban hipertensión arterial y prehipertensión. Esta intervención se llevó a cabo desde mayo del 2015 hasta abril del 2017 en tres centros de salud de Lima (2 en Comas y 1 en Callao), y se compararon los cambios experimentados por las personas durante el estudio. Todos los participantes recibieron consultas personalizadas, reuniones grupales para mejorar el autocuidado y sesiones grupales de educación sobre salud, al igual que mensajes de texto al respecto. Se recurrió a la prueba de la t para datos emparejados y la prueba de la $\chi^{2}$ para establecer la significación estadística de los cambios en los indicadores antes y después de la intervención.

Resultados. Los comportamientos relativos al modo de vida, como el seguimiento de la presión arterial y del peso, el menor consumo de sal, el mayor consumo de frutas y verduras y el mejor control del nivel de estrés, mejoraron durante la intervención $(P<0,001)$. El EuroQol-5D (EQ-5D) mostró mejora $(P<0,001)$, mientras que el índice de masa corporal, el perímetro de la cintura, la presión arterial diastólica y la sistólica de los participantes disminuyeron de manera significativa $(P<0,001)$. El colesterol de las lipoproteínas de baja densidad (LDL-C) y los triglicéridos disminuyeron $(P<0,001)$, mientras que el colesterol de las HDL (HDL-C) aumentó. La filtración glomerular estimada (eGFR) aumentó después del programa $(P<0,001)$.

Conclusiones: este programa de control integral de la PA resultó efectivo para mejorar los indicadores relativos al modo de vida, los niveles de PA y los resultados de laboratorio en las personas que viven en zonas urbanas de ingresos bajos en Perú. Aumentar las oportunidades para la medición de la PA, el manejo sistemático de pacientes con hipertensión arterial y los programas de prevención y educación a nivel comunitario son sumamente importantes para detectar, prevenir y controlar la hipertensión arterial.

Palabras clave Presión sanguínea; atención primaria de salud; estilo de vida saludable; poblaciones vulnerables; Perú.

\section{Eficácia de um programa abrangente de controle da pressão arterial na atenção primária à saúde no Peru}

RESUMO Objetivo. Avaliar a eficácia de um programa abrangente de controle da pressão arterial (PA) na melhoria de indicadores do estilo de vida, dos níveis de PA e dos resultados de exames laboratoriais entre pessoas que vivem em áreas urbanas de baixa renda no Peru.

Métodos. Utilizamos um desenho de estudo prospectivo do tipo pré/pós-intervenção para estudar 1.271 participantes com hipertensão ou pré-hipertensão. A intervenção foi implementada durante 2 anos, de maio de 2015 a abril de 2017, em três centros de saúde em Lima (2 em Comas e 1 em Callao). Comparamos as mudanças nos participantes ao longo do período do estudo. Todos os pacientes participaram de consultas individualizadas, sessões em grupo para educação em saúde e reuniões em grupo regulares para melhorar a autogestão; além disso, receberam mensagens de texto para a educação em saúde. Utilizamos testes t e testes do quiquadrado pareados para determinar a significância das mudanças nos indicadores antes e após a intervenção. Resultados. Comportamentos relacionados ao estilo de vida, tais como o monitoramento do peso e da pressão arterial, a redução do consumo de sal, o maior consumo de frutas e vegetais e o controle do estresse, melhoraram durante a intervenção ( $p<0,001)$. A Escala de Cinco Dimensões EuroQol melhorou $(p<0,001)$, e o índice de massa corporal, a circunferência abdominal e a PA sistólica e diastólica dos participantes diminuíram significativamente $(p<0,001)$. O colesterol de baixa densidade (LDL) e os triglicerídeos diminuíram $(p<0,01)$, e o colesterol de alta densidade (HDL) aumentou. A taxa de filtração glomerular estimada (TFGe) aumentou após o programa $(p<0,001)$.

Conclusões. Este programa abrangente de controle da PA foi eficaz na melhoria de indicadores do estilo de vida, dos níveis de PA e dos resultados laboratoriais entre pessoas que vivem em uma área urbana de baixa renda no Peru. O aumento das oportunidades para a medição da PA, a gestão sistemática de pacientes hipertensos e programas comunitários de prevenção e educação são fundamentais para detectar, prevenir e controlar a hipertensão.

Palavras-chave Pressão sanguínea; atenção primária à saúde; estilo de vida saudável; populações vulneráveis; Peru. 